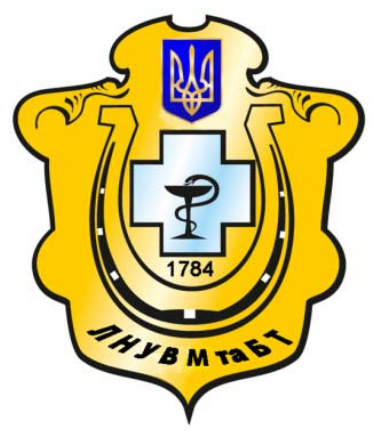

Науковий вісник Львівського національного університету ветеринарної медицини та біотехнологій імені С.З. Гжицького

Scientific Messenger of Lviv National University of Veterinary Medicine and Biotechnologies named after S.Z. Gzhytskyj

doi:10.15421/nvlvet6645

ISSN 2413-5550 print

ISSN 2518-1327 online

$\underline{\text { http://nvlvet.com.ua/ }}$

\title{
Diagnostic problems anemia in alpakas
}

\author{
B. Abramowicz, A. Milczak, D. Bochyńska \\ beata.abramowicz13@gmail.com \\ Uniwersytet Przyrodniczy w Lublinie, Wydziat Medycyny Weterynaryjnej \\ Katedra i Klinika Chorób Wewnętrznych Zwierząt, Lublin, Polska \\ University of Life Sciences in Lublin, Veterinary Medicine Faculty, \\ Department of Internal Diseases, Lublin, Poland
}

\begin{abstract}
In South America, moderate to severe anemia is a relatively common problem in alpacas presented to referral institutions and in those seen in private practices. The anemia is, at times, unexplained, and can be very debilitating. Possible causes of anemia in alpacas are parasitic gastroenteritis, Mycoplasma haemolamae, gastric ulcers, iron deficiency in the diet. Fe deficiency anemia is due to different causes, which lead to too low concentration of Fe in the body and impossibility of heme synthesis.

A case report

Alpaca herd examined which were located near Lublin. The herd numbered 12 animals. Alpacas stayed for two months in the owner. In 7 animals we observed apathy, they became sad with reduced or lack of appetite, thirst reduced or normal. One out of seven alpacas was debilitated, lying, poorly responsive to the environment. We observed sick animals pale mucous membranes in a clinical study. Blood samples and faeces for laboratory animals from the healthy and the sick animals. We drew blood counts and biochemical: concentration of iron and selenium and the Mycoplasma haemolamae. We carried out a study of parasitological of faeces.

Alpacas did not show symptoms, they had all parameters in reference interval. Result selenium concentration in the serum was correct in all exanimated animals. Testing for Mycoplasma haemolamae was negative. The study revealed single eggs gastrointestinal parasites in study of parasitological of faeces.

In sick animals there was observed anemia, microcytic, hypochromic. This indicated iron deficiency. In these cases, iron concentration, ranged from 3.13 to $9.75 \mathrm{mmol} / \mathrm{L}$. However, in other animals, concentration of this element is in the range reference standards (11-29 mmol / L) for adult alpacas. An effective iron dextran treatment to even out the level of serum Fe.

Conclusions

In our case, anemia was caused by nutritional deficiencies of iron, which gave way to the long-term supplementation of this element.
\end{abstract}

Key words: blood, anemia, red blood cells, hemoglobin, hematocrit, iron, alpaca, Mycoplasma haemolamae, stomach ulcers, parasitological examination.

\section{Citation:}

Abramowicz, B., Milczak, A., Bochyńska, D. (2016). Diagnostic problems anemia in alpakas. Scientific Messenger LNUVMBT named after S.Z. Gzhytskyj, 18, 2(66), 220-222.

\section{Wstęp}

Alpaki należą do rodziny wielbłądowatych, tj. ssaków łożyskowych z rzędu parzystokopytnych. Wielbłądowate są ssakami dużymi i bardzo dużymi. Charakteryzują się długą, wygiętą szyją, małą głową, krótkim ogonem i długimi, smukłymi kończynami zakończonymi dwoma palcami (III i IV), pozostałe palce są całkowicie zredukowane. Posiadają trójkomorowy żołądek. Alpaki są zwierzętami przeżuwającymi, ale nie należą do przeżuwaczy. W przeciwieństwie do pozostałych ssaków, wielbłądowate posiadają erytrocyty o owalnym kształcie, bardzo odporne na wahania ciśnienia osmotycznego. Każdy erytrocyt może napęcznieć do $240 \%$ swojej zwykłej objętości, bez ryzyka uszkodzenia. Erytrocyty alpak zachowują dużą mobilność nawet w okresach wzrostu lepkości krwi, związanego z odwodnieniem. Alpaki są zwierzętami socjalnymi tworzącymi grupy rodzinne złożone z dominującego samca, kilku samic i ich potomstwa. Żywią się trawą i liśćmi drzew i krzewów.

$\mathrm{W}$ południowej Ameryce u alpak stosunkowo często obserwuje się niedokrwistość różnie zaawansowaną od łagodnej do ciężkiej postaci. Niejednokrotnie występuje ona $\mathrm{z}$ niewyjaśnionych przyczyn. W większości 
przypadków wśród czynników sprzyjających jej pojawieniu się można zaliczyć pasożyty żołądkowojelitowe najczęściej $\mathrm{z}$ rodziny Trichostrongylidae oraz Strongyloididae, bakteryjne Mycoplasma haemolamae, wrzody żołądka, niedobory żelaza lub selenu w pożywieniu (Foster et al., 2009). Mycoplasma haemolamae jest bakterią rodziny Mycoplasmataceae wykazującą chemotropizm do błony erytrocytów. U alpak wywołuje ona niedokrwistość przebiegającą w postaci od łagodnej do ciężkiej. Najczęściej anemia wywołana tymi patogenami objawia się ospałością, gorączką, a w ciężkich przypadkach nawet śmiercią (Wernery, 2012). Autorka (4) donosi, iż według przeprowadzonych badań większość alpak jest nosicielem Mycoplasma haemolamae, bez widocznych objawów klinicznych. Choroba ujawnia się W wyniku spadku odporności zwierząt, W postaci niedokrwistości z obniżonymi wskaźnikami czerwonokrwinkowymi - erytrocytami, hematokrytem i hemoglobiną (Tornquist et al., 2010; Wernery, 2012). Niedokrwistość z niedoboru Fe jest spowodowana różnymi przyczynami, które prowadzą do zbyt małego stężenia Fe w organizmie i braku możliwości syntezy hemu. Żelazo jest niezbędnym składnikiem grupy hemowej hemoglobiny, a w przypadku jego braku, Hb nie może być wytwarzana w odpowiednich ilościach (Morin et al., 1992; Van Saun, 2006). W literaturze można natknąć się na opis przypadków niedokrwistości spowodowanej niedoborem selenu u wielbłądowatych (Faye and Seboussi, 2009). U tych zwierząt oprócz choroby tzw. «białych mięśni» odnotowano wyraźny spadek liczby krwinek czerwonych, hematokrytu i hemoglobiny. Po zastosowaniu suplementacji Se w diecie powyższe wskaźniki wróciły do prawidłowych wartości fizjologicznych.

\section{Opis przypadku}

Do Katedry i Kliniki Chorób Wewnętrznych Uniwersytetu Przyrodniczego w Lublinie dostarczono alpakę, samicę lat około 2. Właściciel zwierzęcia podał w wywiadzie, że pochodzi ona ze stada liczącego jeszcze 11 innych alpak. Zwierzęta zostały sprowadzone bezpośrednio $\mathrm{z}$ Chile i przebywają $\mathrm{w}$ Polsce od 2 miesięcy. Zaniepokojenie właściciela wzbudził stan zwierzęcia. Alpaka leżała i słabo reagowała na otoczenie. Objawy te wystąpiły dość nagle. W badaniu klinicznym stwierdzono bladość błon śluzowych, duszność mieszaną w spoczynku.

Od zwierzęcia pobrano krew do badań laboratoryjnych morfologicznych i biochemicznych, do probówki $\mathrm{z}$ EDTA i na surowicę. Wykonano badanie hematologiczne krwi, w którym stwierdzono leukopenię i niedokrwistość mikrocytarną, z dość wysoką wartością MCHC. Ponadto w przygotowanym preparacie zaobserwowano anizocytozę i polichromazję krwinek; oraz drobne, okrągłe granatowe twory przypominające wyglądem bakterie. Taki obraz nasunął podejrzenie, iż przyczyną niedokrwistości jest infekcja Mycoplasma haemolamae. Drobnoustrój ten wywołuje u zarażonego zwierzęcia hemolizę wewnątrznaczyniową. Za procesem hemolitycznym mogła też przemawiać wysoka wartość MCHC (Stojecki et al., 2012). Brak doświadczenia w morfologicznej diagnostyce infekcji Mycoplasma haemolamae utrudniał podjęcie ostatecznej decyzji, a nie dysponowano, niestety, możliwością potwierdzenia podejrzenia badaniem serologicznym, czy PCR. Wyniki innych badań nie rozwiewały wątpliwości. Większość wskaźników biochemicznych krwi mieściła się w zakresie norm fizjologicznych. Jedynie stężenie żelaza w surowicy było niskie. Wartość tego pierwiastka w surowicy wynosiła 3,13 $\mu \mathrm{mol} / \mathrm{l}$. Podjęto decyzję o zastosowaniu leczenia oksytetracykliną W dawce $15 \mathrm{mg} / \mathrm{kg}$ oraz dekstranem żelaza w dawce $300 \mathrm{mg}$ na zwierzę pod skórnie. W trzeciej dobie leczenia zwierzę padło.

$\mathrm{W}$ badaniu pośmiertnym u zwierzęcia stwierdzono obecność skupisk wydłużonych, szaro-białych cyst w większości mięśni szkieletowych. Na podstawie badania histopatologicznego rozpoznano masywną inwazję Sarcosporidium spp.

Wobec niepomyślnego zejścia choroby właściciel zwrócił się z prośba o przebadanie pozostałych zwierząt w stadzie liczącym 11 szt. Stan zwierząt był bardzo zróżnicowany.

U części (6 szt.) alpak zaobserwowano apatię, zmniejszony apetyt. W badaniu klinicznym stwierdzono bladość błon śluzowych, pozostałe układy nie odbiegały od norm fizjologicznych. Pozostałe (5 szt.) zwierzęta nie wykazywały żadnych objawów klinicznych i zmian w badaniu klinicznym. Od wszystkich zwierząt pobrano krew do badania hematologicznego i biochemicznego oraz kał do badania parazytologicznego. W badaniu hematologicznym sześciu alpak stwierdzono, podobnie jak u padłej sztuki, niedokrwistość mikrocytarną, z podwyższoną wartością MCHC. W rozmazie krwi zaobserwowano anizocytozę i polichromazję krwinek, stwierdzono także obecność dakrocytów oraz obecność licznych drobnych, linearnych i romboidalnych ciemno eozynofilowych złogów pokrywających powierzchnię większości erytrocytów. Są to najprawdopodobniej kryształy hemoglobiny - są one łatwe do zidentyfikowania i najprawdopodobniej nie mają znaczenia klinicznego. Od 3 zwierząt z 6 wysłano surowicę do badania $\mathrm{W}$ kierunku Mycoplasma haemolamae metoda PCR. Wynik tego badania był ujemny. U pozostałych 5 zwierząt wyniki badania hematologicznego mieściły się $\mathrm{W}$ zakresie norm fizjologicznych. U wszystkich zwierząt oznaczono stężenie żelaza w surowicy. U padłej alpaki stężenie Fe w surowicy było najniższa i wynosiło 3,13 $\mu \mathrm{mol} / \mathrm{l}$. U zwierząt $\mathrm{z}$ niedokrwistością zakres stężenia żelaza wahał się od 5,08 do 9,75 $\mu \mathrm{mol} / \mathrm{l}$. Natomiast u pozostałych alpak stężenie tego pierwiastka mieściło się $\mathrm{w}$ zakresie norm referencyjnych (11-29 $\mu \mathrm{mol} / \mathrm{L})$ dla dorosłych alpak. Ponad to zdecydowano się na oznaczenie stężenia selenu, po konsultacji ze specjalistą od chorób wielbłądowatych z Arabii Saudyjskiej. Konsultant zasugerował bowiem, iż jedną z przyczyn niedokrwistości u wielbłądowatych w jego kraju jest właśnie niedobór selenu. Okazało się, że stężenie tego pierwiastka u wszystkich sztuk oscylowało wokół średnich wartości normy fizjologicznej. W badaniu parazytologicznym kału stwierdzono pojedyncze jaja nicieni żołądkowo-jelitowych z rodziny Trichostrongylidae oraz Strongyloididae. Właścicielowi zasugerowano celowość przeprowadzenia badania 
biopsyjnego mięśni u niektórych sztuk, ten jednak nie wyraził na to badanie zgody.

Zwierzęta odrobaczono preparatem Fenbenat. U wszystkich sztuk zastosowano suplementację dextranu żelaza (Ferrovet $100 \mathrm{mg} / \mathrm{ml}$ ) w dawce $300 \mathrm{mg}$ na dorosłą alpakę. Podano także selen $\mathrm{z}$ witaminą $\mathrm{E}$ (MYOGASTER-E, roztwór do wstrzykiwali dla bydła, owiec i świ, zawierający octanu tokoferylu $100 \mathrm{mg} / \mathrm{ml}$ seleninu sodu bezwodnego $1,315 \mathrm{mg} / \mathrm{ml}-2 \mathrm{ml} /$ sztukę i.m.). Co drugi dzień, przez $14 \mathrm{dni}$, zwierzętom podawano także witaminę B12 w dawce $3000 \mu \mathrm{g}$ na zwierzę podskórnie. Mając na uwadze fakt, że u padłej sztuki stwierdzono sarkosporidiozę, wszystkim sztukom podano domięśniowo Sulfatrim. Zakładano przeprowadzenie dwutygodniowej kuracji sulfonamidem, ale właściciel zauważył, że po injekcjach zwierzęta były osowiałe, a u dwu z nich wystąpił krwiomocz. Odstawiono lek, ale profilaktycznie u wszystkich zwierząt przeprowadzono pięciodniową kurację oksytetracykliną w dawce 15 $\mathrm{mg} / \mathrm{km}$ m.c. domięśniowo. Po zastosowaniu leczenia antybiotykiem, zwierzęta nie wykazywały żadnych objawów chorobowych. Zaczęły interesować się otoczeniem, a ich aktywność powróciła do normy. Podaż dekstranu żelaza, selenu z wiaminą E i witamin z grupy B (Combivit) powtarzano jeszcze dwukrotnie w odstępach 30 dni. Parametry morfologiczne krwi (erytrocyty, Ht i $\mathrm{Hb})$ wróciły w granice norm fizjologicznych. Zwierzęta zaczęły jeść i przybierać na wadze.

\section{Omówienie i wnioski}

Ustalenie etiologii niedokrwistości u alpak jest trudne wobec mnogości przyczyn mogących wywołać ten stan. W omawianym wypadku żaden $\mathrm{z}$ istotnych czynników wywołujących niedokrwistość nie występował w nasileniu, usprawiedliwiającym rozwój tego stanu. Inwazja Sarcosporidium spp. może być powodem utraty łaknienia, spadku masy ciała a także niedokrwistości. Diagnostyka sarcosporidiozy jest jdenak trudna. U żywicieli ostetecznych można wykryć obecność sporocyst w badaniu kału metodą flotacji, natomiast u żywicieli pośrednich, rozpoznanie jest możliwe tylko podczas badania poubojowego lub na podstawie badania biopsyjnego mięśni, o ile w pobranym wycinku znajdą się torbiele (Stojecki et al., 2012).

Brak rozpoznania etiologicznego oraz fatalne zejście choroby u jednej ze sztuk wymusił podjęcie terapii polipragmatycznej. Zwierzęta dobrze zareagowały na podane leki. Trudno jednak ustalić, który z nich okazał się istotnie skuteczny. W tym przypadku najprawdopodobniejszą przyczyną niedokrwistości wydawał się być niedobór żelaza. W oparciu o przeprowadzone badania nie było możliwe ustalenie, czy niedobór ten wynikał z przyczyn żywieniowych, czy też był efektem zaburzeń w obrocie żelaza. Mając na uwadze fakt, że zwierzęta były sprowadzone do Polski wzięto pod uwagę różne przyczyny niedokrwistości, ze szczególnym uwzględnieniem czynników infekcyjnych i inwazyjnych występujących w kraju pochodzenia zwierząt. Ujemny wynik badania PCR w kierunku Mycoplasma haemolame w opisywanym stadzie pozwolił na wykluczenie tej infekcji. Nie przesądza to jednak, że padła sztuka była wolna od infekcji wspomnianym drobnoustrojem. Jak dotąd brak jest danych na temat sposobów transmisji zakażenia w warunkach naszego kraju. Zastosowanie oksytetracykliny $\mathrm{u}$ pozostałych przy życiu zwierząt uzasadniano nie tyle brakiem zaufania do wyników badań PCR, ile podejrzeniem, że przyczyną niedokrwistości może być inna infekcja. W grę mogło wchodzić zakażenie Clostridium perfringens. W Ameryce Południowej infekcje wywołane tym drobnoustrojem spotyka się często u alpak. Czynnikiem usposabiającym do zakażenia są sytuacje stresowe. W przebiegu zakażeń Clostridium perfringens opisywano u ludzi i zwierząt przypadki rozwóju niedokrwistości hemolitycznej.

Trudności w ustaleniu rozpoznania skłaniają do głębszego zastanowienia nad kwestią diagnostyki chorób alpak w Polsce. Wobec wzrostu zainteresowania hodowlą i chowem tych zwierząt konieczne wydaję się opracowanie paneli diagnostycznych dla zwierząt introdukowanych ale także tych wyhodowanych już w kraju. Nie bez znaczenia jest oczywiście kwestia ustalenia wartości referencyjnych poszczególnych wskaźników laboratoryjnych. Należy przypuszczać, że zmiana klimatu i wysokości nad poziomem morza wpływa zwłaszcza na zakresy wskaźników układu czerwonokrwinkowego, dlatego korzystanie $\mathrm{z}$ wartości opracowanych w innych krajach może być zawodne.

\section{Piśmiennictwo}

Tornquist, S.J, Boeder, L., Rios-Phillips, C., Alarcon, V. (2010). Prevalence of Mycoplasma haemolamae infection in Peruvian and Chilean llamas and alpacas. J Vet Diagn Invest. 22, 766-769.

Van Saun, R.J.(2006). Nutritional diseases of South American camelids. Small Ruminant Research. 61, 53-164.

Morin, D.E., Garry, F.B., Weiser, M.G. (1992). Hematologic Features of Iron Deficiency Anemia in Llamas. Vet Pathol. 29, 400-404.

Wernery, U. (2012). Mycoplasmosis in camelids with own investigations. Journal of Camel Practice and Research. 19(2), 135-142.

Faye, B., Seboussi, R. (2009). Selenium in Camel - a review. Nutrients, doi: 10.3390/nu1010030.

Foster, A., Bidewell, C., Barnett, J., Sayers, R. (2009). Haematology and biochemistry in alpacas and llamas. In Practice. 31, 276-281.

Stojecki, K., Karamon, J., Sroka, J., Cencek, T. (2012). Molecular diagnostics of Sarcocystis spp. infections. Polish Journal of Veterinary Sciences. 15(3), 589596.

Стаття надійшла до редакиії 1.10.2016 